\title{
Catholic Identity and Spiritual Well-Being of Students in a Philippine Catholic University
}

\author{
Enrique G. Oracion ${ }^{1}$ and Dennis V. Madrigal² \\ 'Silliman University \\ ${ }^{2}$ University of Negros 0 ccidental-Recoletos \\ ²dennis_madrigal@yahoo.com
}

\section{Abstract}

This paper primarily compares the spiritual well-being of students in a Catholic university classified according to their self-ascribed identity as creative and orthodox Catholics. With the use of a survey questionnaire, the demographic and academic profile and church involvement of students were first established and subsequently associated with their self-ascribed Catholic identity using Chi-square test. Meanwhile, the spiritual wellbeing of students was measured using the standardized 20-item Spiritual Well-Being Scale (SWBS) test developed by Paloutzian and Ellison (1982). The t-test and one-way Analysis of Variance were employed to differentiate the spiritual well-being scores of students grouped according to their demographic and academic profile and church involvement. This paper shows that the orthodox Catholics significantly scored higher in spiritual well-being than the creative Catholics. Thus, teaching the meanings of Catholic beliefs and practices should be enriched with practical relevance so students would consider them not merely as part of Catholic rituals.

Keywords: religious education, catholic identity, spiritual well-being, college students, catholic university, Philippines

\subsection{Introduction}

A Social Weather Stations (SWS, 2018) poll in the last quarter of 2017 showed that the weekly attendance of Catholics at religious or church services had significantly declined statistically to 41 percent from the 64 percent in 1991. This figure was lowest compared to the Muslims that scored highest (98\%) followed by other Christians (67\%) and the Iglesia ni Cristo members (58\%) of the same period. Although there was a slight decline among those from various religious affiliations who said that religion is significant, those who said so scored higher in weekly attendance at religious services. This means that those who considered religion less important correspondingly attended lesser religious services. Does this suggest that Catholics are becoming less religious now, particularly among young people? This is a question that may have bothered many devout Catholics about their young members who departed from Catholic tradition and have shown some signs of vulnerability to the enticement by other religious denominations or sects. 
Sociologist of religion Jayeel Cornelio (2016) provides the context why and how there is a growing disinterest among young Filipino Catholics about the traditional way of expressing their faith but without also disengaging themselves from the Catholic Church. His dynamic approach of interrogating religious identity vis-a-vis Catholic identity allows a more progressive understanding of how young people manifest what they believe as more appropriate avenues of satisfying their quest for spirituality beyond religiosity. In this sense, spirituality is used here to refer to a general disposition towards the world and not associated with any particular religious beliefs or traditions (Chirico 2016). And the binary of being "spiritual but not religious" (Ammerman, 2013) provides an excellent backdropto understand what Cornelio (2016) considers as the emerging de facto typologies of Catholic identity such as the "orthodox" who adheres to traditional beliefs and practices, the "creative" who is selective on what to believe and practice, the "cultural" who simply values church membership but not its teachings and rituals, and the "individualist" who affiliate with the Catholic church but do not believe on it.

Arguably, the growing openness in the interpretations of what it means being Catholic in the Philippines among young students, because of easy access to information through various media, had exposed Catholic academic institutions to the major challenge of pursuing its mission of evangelization or faith formation along with Catholic tradition (Madrigal \& Oracion 2018). Moreover, while Catholic colleges and universities, in particular, have to be true to their mission, they have also to produce graduates that meet the skill requirements of the labor market (Cornelio \& Raffin, 2009). And how the young people view specific issues like divorce, abortion, homosexuality, premarital sex, success in life and so on is not merely a decline in the morality and changing religiosity of Catholic students but also a product of their being critical to what they should believe and practice in response to social and cultural changes around them (Cornelio, 2016).

Corollary to the foregoing observations, Cornelio (2018, p. 88) writes that the challenges of Catholic education in the Philippines to remain relevant could be summarized into "the instrumentalization of education, religious diversification, and the emergence of the Creative Catholics" where the last may be the outcome of the first two challenges. However, these breeds of self-defined young Catholics still value their church affiliation, and they cannot abandon it and join other churches which could satisfy their more liberal reading of what a good Christian ought to be. While they stay as Catholics they give less importance to the sacraments and doctrines, which for them may be purely ritualistic, and replaced these with activities they believed is more pleasing to God like in helping the marginalized people (Cornelio, 2016).

Thus, this paper primarily aims to compare the religious wellbeing (RWB) and existential well-being (EWB) as well as the spiritual well-being (SWB) between students who identified themselves as orthodox and creative Catholics in a Catholic University. Henceforth, it is generally hypothesized that no significant differences exist in the RWB, EWB, and SWB between orthodox and creative Catholics notwithstanding their differentiated involvement in church activities and adherence to Catholic beliefs and practices. In order to have a better understanding of the results, this paper initially examines if the demographic and academic profile as well as the involvement in church activities of these students are associated with their Catholic identity and if they differ or not in their spiritual well-being scores when they are categorized 
based on the foregoing variables. Correspondingly, it was hypothesized that the demographic and academic profile and church involvement of students are not significantly associated with their Catholic identity and that they do not significantly differ on their spiritual well-being scores.

\section{Theoretical and Conceptual Frameworks}

Theoretically, creative Catholics are presumed to be higher in spirituality than in religiosity because of the prime importance they give to a personalized relationship with God while religiosity may be associated more with orthodox Catholics (see also Ammerman, 2013). The creative Catholics referred to in this paper, however, is different from its usage in the book of Bautista (2010, p. 130) that associates this to those involved in inventing or "maintaining some form of anitismo in Christian worship" which is also described as folk Catholicism or the extreme manifestation of Catholic orthodoxy. Thus, the shift in self-ascribed Catholic identity for whatever reasons may affect the quality of life or well-being of individuals as they struggle to live with the ideas and practices they highly valued but unacceptable to others being inappropriate. This is where the use of spiritual well-being scale become relevant because this measures both their "sense of well-being in relationship to God' and their existence or "perception about life's purpose and satisfaction" (Paloutzian \& Ellison, 1982) as Catholics.

Conceptually, between the two dominant Catholic identities in the typologies mentioned by Cornelio $(2016,2018)$ - the orthodox and the creative Catholics-the question on which type has exhibited greater spiritual well-being (SWB) is interesting for further investigation to better appreciate the hypothesized fluidity or flexibility of young people. The assumption is that the pressures and demands from people inside and outside of the Catholic Church may confuse the young, given their demographic and academic profile as well as church involvement, who are yet establishing or solidifying their identities as Catholics. This is particularly more difficult for Catholic students who have to meet the expectations of their parents who purposely send them to Catholic schools as a family tradition and of their religious studies teachers, which may include priests and nuns, who formally convey to them Catholic teachings as requirements for academic promotion. In contrast, those who score higher in SWB may be more comfortable in the manner they negotiated orthodox and creative identities.

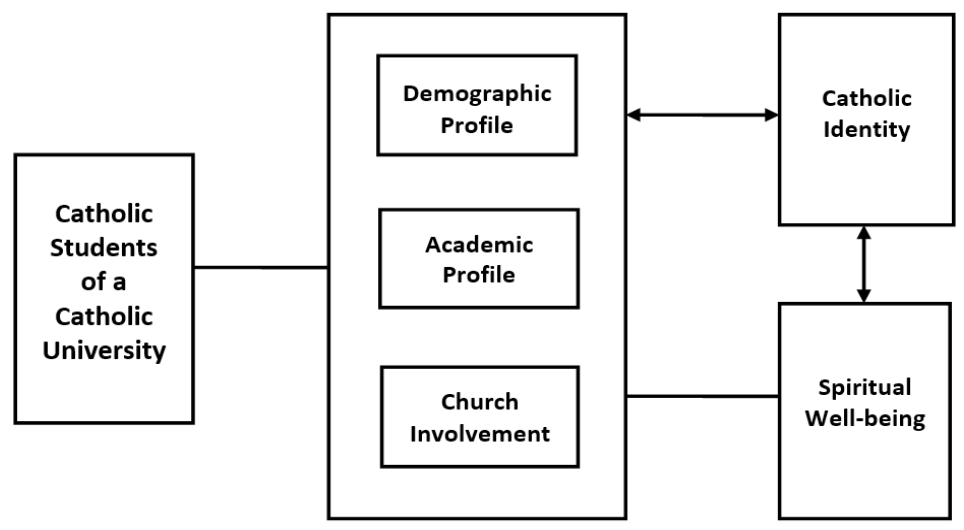

Figure 1. Conceptual Model 


\subsection{Methodology}

The study was conducted in a Catholic University in the central Philippines which is one of the seven academic institutions in the country run by the foremost Spanish religious Order who came during the colonization of the Philippines. The students who participated in the study were mostly on their third and fourth year in college. There were no first and second year students at the time of the study because they were yet in Grades 11 and 12 as a result of the $\mathrm{K}$ to 12 curriculum implementation of the Philippine Department of Education. The students included in the study were considered purposive samples because they were intentionally taken according to their self-ascribed Catholic identity after an initial survey and that they had already taken subjects pertinent to Catholic religion during their first and second year in college. The students had agreed to participate after they were explained about the purpose of the study.

The subjects taken by students to reinforce the assumption that they were already familiar with Catholic teachings included Basic Catholic Doctrine that discusses about revelation and faith, the Catholic faith, and the sacred scripture; Christology that examines the life of Jesus particularly His historical reality, ministry and Paschal Mystery; Christian Morality that presents the fundamental moral concepts on human person, freedom, conscience, law, sin and grace within the context of the Christian formation; and Church and Sacraments that describes the fundamental aspects of the church, history of the Roman Catholic Church, and ritual sacraments. They were enrolled in two sections of Religious Education subjects at the time of the survey.

The students answered the survey questionnaire and the purchased 20-item Spiritual Well-Being Scale (SWBS) test, composed of the Religious Well-Being
(RWB) and Existential Well-Being (EWB) subscales, developed by Paloutzian and Ellison (1982). No reliability test was conducted of this instrument as used in the present study because it is already standardized and considered a good measure of well-being or quality of life evident in the results of several related studies that covered religious and non-religious as well as normal and clinical samples of respondents. Clinical samples or those with health problems, either mental or physical, significantly scored lower in SWB than the normal samples (Bufford, Paloutzian, \& Ellison 1991). The SWB of an individual is the average of the combined scores of the RWB subscale that assesses "a satisfying relationship with God" and the EWB subscale that measures "sense of life satisfaction and purpose" (Genia, 2001, Malinakova et al. 2017). This suggests that the SWB, given its religious dimension, is a useful measure of knowing the young people in distressful life situation because of social pressure like those who departed from orthodox Catholic beliefs and practices. Thus, the use of this tool among Filipino students was a way also of validating the results from elsewhere and to confirm its applicability in various cultural contexts.

The chi-square test was used to find significant associations of the demographic profile such as sex, age, and birth order; academic profile which includes courses and academic level; and church involvement which covers memberships in church organizations, involvement in church ministry, and attendance in every Sunday masses with the self-ascribed Catholic identity of students. Meanwhile, the t-test was used to measure significant differences in the spiritual wellbeing scores when the students were categorized according to their profile, church involvement, and Catholic identity. Only in comparing the spiritual wellbeing scores among students from different courses where the single Analysis of Variance (ANOVA) was 
used. Finally, the two-tailed test was employed in making decisions whether to accept or reject the null hypotheses.

\subsection{Results}

Profiling Catholic identity. The students were asked to encircle in the questionnaire particular characteristics which they felt best described their being Catholics, and the answer was subsequently fitted to the de facto typology of Catholic identity based on the work of Cornelio (2016) as described earlier. The analysis showed that about 36 (51.43\%) of the initial sample of 72 students fitted to the descriptions of "creative Catholics" who selected only certain beliefs and practices presumed to demonstrate their membership with Catholic religion. Twenty-eight (40.00\%) considered themselves as "orthodox Catholics" who admitted to being very high on practice and adherence to Catholic traditions, and $6(8.57 \%)$ assumed the identity of "cultural Catholics" who joined the Church and practiced certain rituals on particular occasions but did not believe much of its teachings. The decision was to compare only the responses of creative ( $\mathrm{n}=36$ or $56.25 \%$ ) and orthodox ( $n=28$ or $43.75 \%$ ) Catholics, hence the final sample size was 64 , because of the limited number of "cultural Catholics" in the initial sampling conducted. Nevertheless, this distribution of Catholic identities among the young is consistent with the findings of Cornelio (2016) among the cases he investigated.

The female students (60.94\%) outnumbered male students (39.06\%) in the sample. The former was also dominantly orthodox Catholics (75.00\%) as compared to the latter who identified with the creative Catholics (50.00\%). The majority belong to age group 20 and above (56.25\%) because this group of students, according to an official of the University, had a good number who work at the same time study to earn a college degree. They were irregular students evident in their age and the number of years they had stayed in this university. This age group is also dominantly composed of creative Catholics (69.44\%) unlike those students in the 18-19 age group where about 61 percent considered themselves as orthodox Catholics. Only 31 percent were eldest among their siblings, and a significant number in this birth order considered themselves creative Catholics (41.67\%) if compared to the other younger siblings, were 82 percent admitted to being orthodox Catholics as compared to 58 percent creative Catholics.

Table 1 shows that the sex, age, and birth order of students are found to be significantly associated with their being orthodox or creative Catholics. The distribution or responses points out that the female students tend to be more orthodox Catholics than the male students who are equally represented the two identity typologies. The younger students are likewise more orthodox who must have diligently followed Catholic practices as taught by their parents and in school similar to the situation of students who are younger in the birth order. The older students who must have been exposed to other religions outside of the school and more critical of their observations about the Catholic Church tend to be more open of their faith and become creative Catholics. Impliedly, maturity and getting more independent-minded may also explain the shift in self-ascribed Catholic identity from being orthodox to being creative. 
Table 1. Demographic Profile and Catholic Identity of Students

\begin{tabular}{|c|c|c|c|}
\hline \multirow{2}{*}{ Demographic Profile } & \multicolumn{2}{|c|}{ Catholic Identity } & \multirow{2}{*}{ Total (\%) } \\
\hline & Orthodox (\%) & Creative (\%) & \\
\hline \multicolumn{4}{|l|}{ Sex } \\
\hline Male & $7(25.00)$ & $18(50.00)$ & $25(39.06)$ \\
\hline Female & $21(75.00)$ & $18(50.00)$ & $39(60.94)$ \\
\hline \multicolumn{4}{|c|}{ Chi-square $=4.14, d f=1, p$-value $=0.04 *$, Significant } \\
\hline \multicolumn{4}{|c|}{ Age Group in Years } \\
\hline $18-19$ & $17(60.71)$ & $11(30.56)$ & $28(43.75)$ \\
\hline 20 and above & $11(39.29)$ & $25(69.44)$ & $36(56.25)$ \\
\hline \multicolumn{4}{|c|}{ Chi-square $=5.82, d f=1, p$-value $=0.01 *$, Significant } \\
\hline \multicolumn{4}{|c|}{ Birth Order } \\
\hline Younger siblings & $23(82.14)$ & $21(58.33)$ & $44(68.75)$ \\
\hline Eldest & $5(17.86)$ & $15(41.67)$ & $20(31.25)$ \\
\hline \multicolumn{4}{|c|}{ Chi-square $=4.16, d f=1, p$-value $=0.04^{*}$, significant } \\
\hline
\end{tabular}

Meanwhile, no significant association is noted between the courses and the Catholic identity of students although a cursory analysis of the percentage distribution of data in Table 2 would show that business students (44.45\%) tend to be more creative Catholics compared to the social science $(42.86 \%)$ and science and technology (25.00\%) students who appear to be more orthodox Catholics. A significant association is present between the academic level of students and their self-ascribed Catholic identity. Among students up to the third year in college, 82 percent admitted to being orthodox Catholics which seems to support the earlier data that the younger students by age and birth order tend to be orthodox in their beliefs and practices as well.

Table 2. Academic Profile and Catholic Identity of Students

\begin{tabular}{|c|c|c|c|}
\hline \multirow{2}{*}{ Academic Profile } & \multicolumn{2}{|c|}{ Catholic Identity } & \multirow{2}{*}{ Total (\%) } \\
\hline & Orthodox (\%) & Creative (\%) & \\
\hline \multicolumn{4}{|l|}{ Course } \\
\hline Business & $9(32.14)$ & $16(44.45)$ & $25(39.06)$ \\
\hline Social Science & $12(42.86)$ & $12(33.33)$ & $24(37.50)$ \\
\hline Science and Technology & $7(25.00)$ & $8(22.22)$ & $15(23.44)$ \\
\hline \multicolumn{4}{|c|}{ Chi-square $=1.043, d f=2, p$-value $=0.594$, Not significant } \\
\hline \multicolumn{4}{|l|}{ Academic Level } \\
\hline Up to third year & $23(82.14)$ & $21(58.33)$ & $44(68.75)$ \\
\hline Fourth year & $5(17.86)$ & $15(41.67)$ & $20(31.25)$ \\
\hline \multicolumn{4}{|c|}{ Chi-square $=4.156, d f=1, p$-value $=0.041^{*}$, Significant } \\
\hline
\end{tabular}


Does this mean that more years in a Catholic university have made students more critical and liberal in their interpretation of biblical teachings and away from orthodoxy, which is associated with Catholic religious tradition? Alternatively, is it because among those self-ascribed orthodox Catholics, who are majority up to the third year in college, had just recently taken subjects pertinent to Catholic religious faith formation. Retention of Catholic religious teachings is still high, which is also reinforced by their involvement in church activities in the university. So, what is likewise interesting to examine is how the church involvement of students had strengthened their identification with this faith aside from how this was influenced by classroom instruction.

Church activities and Catholic identity. It may be sad to note that despite being in a Catholic university only 25 percent of all the respondents were members of campus religious organizations, 30 percent were involved in church ministry, and 36 percent regularly attended mass every Sunday. Nonetheless, of the decreasing number who are active Catholics, 36 percent were orthodox Catholics who were members of campus religious organizations as compared to the 17 percent among the creative Catholics, although the difference is statistically insignificant. This result is only suggestive of the possibility that stronger adherence to Catholic religious beliefs and practices may be earned through active membership in the religious organization of students. Reinforcement by peers with similar religious identity in their Catholic beliefs and practices is always possible when the students regularly interact and inspire each other during faith-related activities in their organizations.

Table 3. Church Activities and Catholic Identity of Students

\begin{tabular}{|c|c|c|c|}
\hline \multirow{2}{*}{ Church Activities } & \multicolumn{2}{|c|}{ Catholic Identity } & \multirow{2}{*}{ Total (\%) } \\
\hline & Orthodox (\%) & Creative (\%) & \\
\hline \multicolumn{4}{|l|}{ Religious Organization } \\
\hline Member & $10(35.71)$ & $6(16.67)$ & $16(25.00)$ \\
\hline Non-member & $18(64.29)$ & $30(83.33)$ & $48(75.00)$ \\
\hline \multicolumn{4}{|c|}{ Chi-square $=3.048, d f=1, p$-value $=0.081$, Not significant } \\
\hline \multicolumn{4}{|c|}{ Church Ministry } \\
\hline Involved & $13(46.43)$ & $6(16.67)$ & $19(29.69)$ \\
\hline Not involved & $15(53.57)$ & $30(83.33)$ & $45(70.31)$ \\
\hline \multicolumn{4}{|c|}{ Chi-square $=6.683, d f=1, p$-value $=0.010^{*}$, Significant } \\
\hline \multicolumn{4}{|l|}{ Mass Attendance } \\
\hline Every Sunday & $16(57.14)$ & $7(19.44)$ & $23(35.94)$ \\
\hline Not every Sunday & $12(42.86)$ & $29(80.56)$ & $41(64.06)$ \\
\hline Chi-square $=9.722, d f=1, p$-val & $.003^{* *}$, Significant & & \\
\hline
\end{tabular}

However, what is also more interesting to highlight in Table 3 is the manner by which the involvement of the respondents in church ministry such as being catechists, lectors, altar servers, choir members and volunteers in outreach activities have significantly differentiated them concerning 
their identity as Catholics. Among those who were reportedly involved in church ministry, a significant number came from among those self-ascribed orthodox (46.43\%) than the creative Catholics (16.67\%). Of the latter group, 83 percent admittedly were not involved in church ministry compared to the 54 percent of the orthodox Catholics. Correspondingly, the respondents who attended church services every Sunday were orthodox Catholics (57.14\%) while those who failed to regularly hear Sunday masses considered themselves as creative Catholics (80.56\%). Clearly, the pattern of involvement in church ministry and attendance in Sunday masses are significantly associated with the Catholic identity of students who self-ascribed themselves as orthodox Catholics. Therefore, being only members in church organizations but without active involvement in their activities does not ensure having orthodox Catholic identity.

Measuring spiritual well-being. On a scale of 1 to 6 , the SWB scores of all the respondents, on the average, is 4.86 , and this is already high, suggesting positive well-being. Having SWB scores at or near the ceiling of the scale is expected similar to the observations of Bufford et al. (1991) because the respondents were all enrolled in a Catholic university and the nature of some statements in the test relate to God. In the analysis of Paloutzian and Ellison (1982, p. 233) of their data relative to the other measures of quality of life, they found out that respondents who have higher SWB scores tend to be "less lonely, more socially skilled, higher in self-esteem, and more intrinsic in their religious commitment."

Although Paloutzian and Ellison (1982) had already remarked based on their works and related studies that generally age and sex are not related to SWB scores or they do not vary, our data in Table 4 suggest that significant differences exist, using t-Test for independent samples, between male and female samples and between younger and older samples. The female students and those aging 18 and 19 years old tend to have higher SWB scores. The respondents did not differ in SWB scores when these were compared according to their birth order.

Table 4. Demographic Profile and Spiritual Well-being of Students

\begin{tabular}{|c|c|c|c|c|}
\hline Demographic Profile & $\begin{array}{c}\text { SWB Mean Score } \\
\text { (Variance) }\end{array}$ & t-value & p-value & Remarks \\
\hline \multicolumn{5}{|l|}{ Sex } \\
\hline Male & $4.59(0.66)$ & \multirow{2}{*}{2.558} & \multirow{2}{*}{$0.013^{*}$} & \multirow{2}{*}{ Significant } \\
\hline Female & $5.03(0.32)$ & & & \\
\hline \multicolumn{5}{|l|}{ Age (Years) } \\
\hline $18-19$ & $5.13(0.27)$ & \multirow{2}{*}{2.832} & \multirow{2}{*}{$0.006^{* *}$} & \multirow{2}{*}{ Significant } \\
\hline 20 and above & $4.65(0.58)$ & & & \\
\hline \multicolumn{5}{|l|}{ Birth Order } \\
\hline Younger siblings & $4.81(0.41)$ & \multirow{2}{*}{0.966} & \multirow{2}{*}{0.338} & \multirow{2}{*}{ Not significant } \\
\hline Eldest & $4.99(0.67)$ & & & \\
\hline
\end{tabular}


Moreover, the SWB scores of students do not also significantly differ when these were compared according to their courses and year levels although those in the science and technology programs and in their fourth year level have lower scores (Table 5). The absence of significant differences in their SWB scores may be due to the fact that these students are all from the same religious university and exposed to the same religious teachings inside the classrooms. However, these teachings cannot totally be expected also as being seriously practiced by all the students when they are outside the campus like in their personal expressions of their faith and church involvement which tells their self-ascribed Catholic identity.

Table 5. Academic Profile and Spiritual Well-being Scores of Students

\begin{tabular}{|c|c|c|c|c|}
\hline Academic Profile & $\begin{array}{l}\text { SWB Mean } \\
\text { Score } \\
\text { (Variance) }\end{array}$ & Value & p-value & Remarks \\
\hline Courses & & ANOVA & & \multirow{4}{*}{ Not significant } \\
\hline Business & $4.93(0.43)$ & \multirow{3}{*}{1.114} & \multirow{3}{*}{0.335} & \\
\hline Social Sciences & $4.94(0.36)$ & & & \\
\hline Science and Technology & $4.63(0.80)$ & & & \\
\hline Year Level & & $\mathrm{t}$-Test & & \\
\hline Up to Third Year & $4.93(0.43)$ & \multirow{2}{*}{1.316} & \multirow{2}{*}{0.256} & \multirow{2}{*}{ Not significant } \\
\hline Fourth Year & $4.71(0.62)$ & & & \\
\hline
\end{tabular}

${ }^{*} p<0.05$

Table 6. Church Activities and Spiritual Well-being Scores of Students

\begin{tabular}{lcccc}
\hline Church Activities & $\begin{array}{c}\text { SWB Mean Score } \\
\text { (Variance) }\end{array}$ & t-value & p-value & Remarks \\
\hline $\begin{array}{l}\text { Church Organization } \\
\text { Member }\end{array}$ & $\begin{array}{l}5.23(0.21) \\
\quad 4.74(0.53)\end{array}$ & 2.563 & $0.013^{*}$ & Significant \\
$\quad \begin{array}{l}\text { Non-member } \\
\text { Church Ministry } \\
\quad \text { Involved }\end{array}$ & $\begin{array}{l}5.09(0.21) \\
\quad 4.76(0.58)\end{array}$ & 1.736 & 0.088 & Not significant \\
$\quad$ Not involved & & & & \\
\hline $\begin{array}{l}\text { Mass Attendance } \\
\text { Every Sunday }\end{array}$ & $5.12(0.35)$ & 2.276 & $0.026^{*}$ & Significant \\
$\quad$ Not every Sunday & $4.72(0.52)$ & & &
\end{tabular}


Church activities and spiritual well-being. Consistent with the earlier findings that involvement in church activities was associated with self-ascribed Catholic identity, the SWB scores of the respondents were likewise significantly differentiated by their membership in church organizations and regular attendance in Sunday church service. Members of church organizations and those who heard masses every Sunday have significantly higher SWB scores (5.23 and 5.12, respectively) which is also true among respondents involved in church ministry but the difference compared to those not involved is not significant-it is only suggestive which may be due to sampling bias requiring more samples. Nonetheless, the data suggest that the orthodox Catholics reportedly demonstrated adherence to church beliefs and practices in their involvement in the rituals and ceremonies of the Catholic Church as an institution.

Table 7. Catholic Identity and Spiritual Well-being Component Scores of Students

\begin{tabular}{|c|c|c|c|c|}
\hline Catholic Identity & Mean Score (Variance) & t-value & p-value & Remarks \\
\hline & Religious Well-being & \multirow{3}{*}{3.131} & \multirow{3}{*}{$0.003^{* *}$} & \multirow{3}{*}{ Significant } \\
\hline Orthodox & $5.49(0.20)$ & & & \\
\hline Creative & $4.91(0.79)$ & & & \\
\hline & Existential Well-being & \multirow{3}{*}{1.958} & \multirow{3}{*}{0.055} & \multirow{3}{*}{ Not significant } \\
\hline Orthodox & $4.76(0.20)$ & & & \\
\hline Creative & $4.40(0.80)$ & & & \\
\hline & Spiritual Well-being & \multirow{3}{*}{2.811} & \multirow{3}{*}{$0.007^{* *}$} & \multirow{3}{*}{ Significant } \\
\hline Orthodox & $5.13(0.14)$ & & & \\
\hline Creative & $4.66(0.67)$ & & & \\
\hline
\end{tabular}

${ }^{* *} p<0.01$

Catholic identity and spiritual well-being. The foregoing observations could be further ascertained by comparing first the scores of the respondents by the two SWB components, religious well-being (RWB), and existential well-being (EWB), and then according to the composite SWB scores. Expectedly, using t-Test for independent samples in comparing mean scores, the orthodox Catholics have significantly higher RWB scores (5.49) and tend to be homogenous with a variance of 0.20 as compared to the creative Catholics (4.91) with 0.79 as a variance. Although the orthodox Catholics have higher EWB scores (4.76), this is not significantly higher compared to the scores (4.40) of creative Catholics. The absence of significant difference, however, may be taken also as an indicator that both the orthodox and creative Catholics are equally satisfied with the quality of their lives as students and family members although they may differ in their religious well-being because of their interpretation of what it means to be a "good" Catholic (see also Cornelio 2016).

However, traces of being uncomfortable regarding their situation, perhaps due to the social pressure toward their self-ascribed identity as creative Catholics, is evident in their composite SWB scores. The orthodox Catholics have significantly 
higher over-all SWB scores (5.13) with lesser variance (0.14) as compared to the lower score of the creative Catholics (4.66) but with more significant variance (0.67). The lesser variances tell that the orthodox Catholics were homogenous on their scores, implying more focused and decisive answering of the SWB test. In contrast, the creative Catholics have four times greater variances suggesting heterogeneous responses-meaning they have lower concurrence among themselves on specific items or statements which they have to agree or disagree with in the SWB scale. Comparatively, despite that the over-all SWB score is already high, the self-ascribed creative Catholics have lower spiritual well-being compared to the orthodox with individual variances similar in religious well-being scores.

\subsection{Discussion}

The data suggest that Catholic identity is gendered in so far as the sample of students in this study is concerned. More female students identified themselves as orthodox compared to the males who appeared to be more creative in expressing their faith in God, and this may be a result of the socialization of children in the family. In the Philippines, like other developing Asian countries (Basu, Zuo, Lou, Acharya, \& Lundgren 2017), daughters are usually closer to mothers and considered them as role models which redound to their being more religious than their brothers. This further means that if mothers are devout Catholics or even the fathers, most likely the daughters would generally grow up as similar kind of individuals in terms of faith. Besides, daughters are expected to be well-behaved, and that already includes being religious and morally upright. Older women are commonly observed to attend masses regularly, and some even volunteer in many church activities such as leading the rosary prayer, serving as lectors or catechists up to cleaning, attending the altar, and so on. These must have influenced the young female students to think of orthodoxy as a norm for women. The findings were affirmed by a study conducted by Buchko (2004) who found that women had more sense of God's activity and presence in their day-to-day life and demonstrated religious devotion and reverence compared to men. Madrigal and Oracion (2018) also reported that women are more religious and spiritual compared to men.

The age and birth order data of students in relation to their self-ascribed Catholic identity also show a certain pattern. The categories of older students and the eldest among siblings tend to be composed more of creative Catholics. This implies that having access to various information and gaining maturity relative to age, which expanded the range of their perspectives, must have made these students more critical about the Catholic beliefs and practices thrown upon them by their parents as they grow up and by their religion teachers as mandated learning competencies being enrolled in a Catholic university. Learning retention was higher when they just recently completed the institutionally mandated subjects related to the Catholic religion, which they are supposed to take during their first and second year in college. Among the students that have some participation in church-related activities, which was incidentally not so many, and attended mass every Sunday must have enriched their being orthodox in beliefs and practices. Unfortunately, there is already a decreasing trend of this kind of students in this university wherein 70 percent were reportedly not actively involved in church activities (see Table 3).

Moreover, how does the Catholic identity of students compare with their spiritual well-being? 
If religiosity, characterized by strict adherence to traditional church beliefs and practices, is paired with Catholic identity and that religiosity is linked with spiritual well-being, then the latter is associated with a Catholic identity. According to Hill and Hood (1999), forms of traditional religious beliefs and practices can activate one's spirituality if done in the context of the search for the sacred. In fact, in another paper using the same data in this current article, we had established a statistically significant relationship between Catholic religiosity and spiritual well-being (Madrigal \& Oracion 2018). Simply put, religious Catholics who identified themselves as orthodox have a higher average score in spiritual well-being than the creative Catholics (see Table 7). The data imply that to be relevant, Catholic academic institutions with a significant number of creative Catholics should re-examine the manner they deliver Catholic teachings to young students if this is still appropriate to the changing times with topics reflective of current realities and demands (see Cornelio 2018).

But is having an increasing number of creative Catholics among students in a Catholic university problematic? The answer depends on one's perspective. It is a failure if the primary mission is to produce orthodox Catholics, but it is a success if these creative Catholics had homogenously scored higher in spiritual well-being comparable with the orthodox Catholics. Therefore, there is nothing wrong with being creative Catholics as long as the students maintain and demonstrate their Catholic faith in a manner that still brings them closer to God and in their relationship with other people, and are satisfied with how they demonstrated their faith as reflected in their spiritual well-being scores. They may not be religious enough as to the forms and frequencies of praying or worshipping, but they have to be consistent in demonstrating Catholic faith from the teachings of the university and in their relationship with others, the Church and God. However, the data show some kind of ambivalence among creative Catholics evident in the way they scored with higher variances in the spiritual well-being scale as compared with the orthodox Catholics.

\subsection{Conclusion}

This paper has established that there is a significant difference in the religious well-being mean score between the orthodox and creative Catholics as they also differ in their involvement in church activities which presumably are expressions and reinforcements of their self-ascribed identities. Although they do not significantly differ in their existential well-being mean score, the data show that the orthodox Catholics have a higher mean score as compared to the creative Catholics. As a result, the mean of the two components, which represents the spiritual well-being of students, shows that the orthodox Catholics outscored the creative Catholics. The self-identification of orthodox Catholics, according to the description presented to them to select from during the survey was consistent with the results of the SWB test administered to them. The low variance in the SWB scores of the orthodox compared to the creative Catholics further implies that the students who identified themselves with the first group are more explicit about their religious identity.

It is recommended that the university should clarify to students the meanings of certain Catholic beliefs and practices taught in religion subjects rather than to expect them to memorize and perform certain rituals in church or school. The students who find practical relevance of what they are expected to learn and do in the church may be more enticed to become members of church organizations, to 
participate in church ministry and to regularly attend Sunday masses. The units in the university tasked in the spiritual and social formation of students should also review the contents and pedagogy of religious instruction to become consistent to the kind of students at present who are flooded with new information and misinformation through the internet and social media. The bulk of information that they cannot meaningfully digest may impair the way they think and interpret their being Catholics. Also, they can easily be drifted to other religions if they are not adequately guided in navigating the waves of religious ideas that come their way.

\section{Acknowledgment}

This paper is an improved version of what was presented during the Philippine Sociological Society National Conference held in Siquijor State College, Larena, Siquijor in the Philippines on October 4-6, 2018. The study was made possible by a Professorial Chair Grant to the lead author through Silliman University and supported by a gift from Dr. Romeo Ariniego, an Outstanding Sillimanian, in the memories of Drs. Hubert and Harriet Reynolds, former Silliman University professors, for their legacies in the fields of Anthropology.

\section{References}

Ammerman, N. T. (2013). Spiritual but not religious? Beyond binary choices in the study of religion. Journal for the Scientific Study of Religion, 52(2), 258-278.

Basu, S., Zuo, X., Lou, C., Acharya, R., \& Lundgren, R. (2017). Learning to be gendered: gender socialization in early adolescence among urban poor in Delhi, India, and Shanghai, China. Journal of Adolescent Health, 61(4), S24-S29.

Bautista, Julius J. (2010). Figuring Catholicism: An ethnohistory of the Santo Niño de Cebu. Quezon City: Ateneo de Manila University Press.

Buchko, K. J. (2004). Religious beliefs and practices of college women as compared to college men. Journal of College Student Development, 45(1), 8998.

Bufford, R. K., Paloutzian, R. F., \& Ellison, C. W. (1991). Norms for the Spiritual Weil-Being Scale. Journal of psychology and theology, 19(1), 56-70.

Chirico, F. (2016). Spiritual well-being in the 21st century: It's time to review the current WHO's health definition. Journal of Health and Social Sciences, 1(1), 11-16.

Cornelio, J. S., \& Raffin, A. (2009). The Catholic Church and education as sources of institutional panic in the Philippines. Asian Journal of Social Science, 37(5), 778-798.

Cornelio, J.S. (2016). Being Catholic in the contemporary Philippines: Young people reinterpreting religion. USA: Routledge.

Cornelio, Jayeel S. (2018). Young people and the challenges of religious education in the Philippines. In Fabrizio Meroni (ed.) Youth, the Catholic Church, and religions in Asia. Italy: Urbaniana University Press. Pp. 79-112.

Genia, V. (2001). Evaluation of the spiritual wellbeing scale in a sample of college students. The International Journal for the Psychology of 
Religion, 11(1), 25-33.

Hill, P. C., \& Hood, R. W. (Eds.). (1999). Measures of religiosity (pp. 119-58). Birmingham, AL: Religious Education Press.

Madrigal, D.V. and Oracion, E. G. (2018). Religiosity and spiritual well-being of students in a Philippine Catholic university. Paper presented during the Philippine Sociological Society 2018 National Conference held in Siquijor State College, Larena, Siquijor, October 4-6, 2018.

Madrigal, D. V., \& Oracion, E. G. (2018). Rethinking Catholic Education: Experiences of Teachers of a Catholic University. Recoletos Multidisciplinary Research Journal, 6(1), 13-26.

Malinakova, K., Kopcakova, J., Kolarcik, P., Geckova, A. M., Solcova, I. P., Husek, V., ... \& van Dijk, J. P. (2017). The Spiritual Well-Being Scale: Psychometric evaluation of the shortened version in Czech adolescents. Journal of religion and health, 56 (2), 697-705.

Paloutzian, R. F., \& Ellison, C. W. (1982). Loneliness, spiritual well-being and the quality of life. Loneliness: A sourcebook of current theory, research and therapy, 224-237.

Social Weather Stations (2018). Attendance at religious services among adults, Philippines, 1991-2017, Retrieved on 2 September 2018 from https://www.sws.org.ph/swsmain/artcldisppage /?artcsyscode=ART-20180328121738 